\title{
PHYTOREMEDIATION POTENTIAL OF ENHANCED TOBACCO IN SOIL CONTAMINATED WITH HEAVY METALS
}

\author{
Violina Angelova ${ }^{354}$ \\ https://doi.org/10.31410/itema.2018.1049
}

\begin{abstract}
A comparative research on the impact of organic meliorants on the uptake of heavy metals, micro and macroelements and phytoremediation potential of enhanced tobacco NBCu 10-8F3 has been carried out. The soil used in this experiment was sampled from the vicinity of the Non-Ferrous-Metal Works near Plovdiv, Bulgaria. The pot experiment was a randomized complete block design containing nine treatments and three replications (27 pots). The treatments consisted of a control (no organic meliorants) and compost and vermicompost meliorants (added at 5\%, 10\%, 15\% and 30\%, recalculated based on dry soil weight). Upon reaching commercial ripeness, the tobacco plants were gathered. Heavy metals, micro and macroelement contents in roots, stems and leaves of tobacco were analyzed by the method of the microwave mineralization. To determine the elements in the samples, inductively coupled emission spectrometry (Jobin Yvon Emission - JY 38 S, France) was used. The distribution of the heavy metals, micro and macroelements in the organs of the enhanced tobacco has a selective character and depended above all on the parts of the plants and the element that was examined. $\mathrm{Pb}, \mathrm{Zn}, \mathrm{Cu}, \mathrm{Fe}, \mathrm{Mn}, \mathrm{P}$ and $\mathrm{Mg}$ distribution in tobacco decreases in the following order: roots > leaves $>$ stems, and for $C d, K$, and $C a$ - leaves $>$ roots $>$ stems. The high concentration of $\mathrm{Cd}$ in the leaves and the high translocation factor indicate the possibility of enhanced tobacco to be used in phytoextraction.

Tested organic amendments significantly influenced the uptake of heavy metals, micro and macroelements by the roots, stems and leaves of tobacco. A correlation was found between the quantity of the mobile forms and the uptake of $\mathrm{Pb}, \mathrm{Zn}$ and $\mathrm{Cd}$ by the enhanced tobacco. The compost and vermicompost treatments significantly reduced heavy metals concentration in leaves and increased uptake of K, Ca and Mg. The 30\% compost and 30\% vermicompost treatments led to the maximal reduction of heavy metals in enhanced tobacco NBCu 10-8F3. The addition of compost and vermicompost further reduces the ability to digest the heavy metals in the leaves, and phytoremediation potential of enhanced tobacco NBCu 10-8F3.
\end{abstract}

Keywords: heavy metals, micro and macroelements, organic meliorants, enhanced tobacco $\mathrm{NBCu} 10-8 \mathrm{~F} 3$, phytoremediation

\section{INTRODUCTION}

$\mathrm{P}$ hytoremediation can be defined as the combined use of plants, soil amendments and agronomic practices to remove pollutants from the environment or to decrease their toxicity [1]. This technique has many advantages compared with other remediation procedures - low economic costs and the possibility of being applied to soils, causing a minimum environmental impact. As a technology based on the use of plants, the success of phytoremediation will mainly depend on the proper selection of plants. Many researchers

\footnotetext{
${ }^{354}$ Agricultural University-Plovdiv, 12 Mendeleev street, Plovdiv, Bulgaria
} 
examine the rapidly growing, high biomass plants, including agronomic crops for their ability to tolerate and accumulate metals in their shoots.

Tobacco is a crop that has an exceptional ability to accumulate more $\mathrm{Cd}$ in its leaves than any other crop [2-3] and is an efficient cadmium accumulator [4]. Guadagnini et al. [4] developed by means of conventional in vitro-breeding and selection techniques, 106 somaclonal variants of tobacco (Nicotiana tabacum ssp.) with increased metal tolerance, accumulation and extraction properties. The authors found that 17 of these somaclonal tobacco variants showed an improved heavy metal shoot uptake and phytoextracted 1.2-2.0 times more $\mathrm{Cd}$ and $\mathrm{Zn}$ than non-modified mother-plants. Herzig et al. [5] confirmed enhanced shoot metal removals up to a factor 1.8 for $\mathrm{Cd}, 3.2$ for $\mathrm{Zn}$ and 2.0 for $\mathrm{Pb}$ in soil contaminated by industrial sewage sludge and up to a factor 12.4 for $\mathrm{Cd}, 13.7$ for $\mathrm{Zn}$ and 13.5 for $\mathrm{Pb}$ in acid sandy soil contaminated by deposits from a zinc smelter for best tobacco variants $\mathrm{NBCu} 10-8 \mathrm{~F} 1$ and $\mathrm{NBCu} 10-4 \mathrm{~F} 1$ [6].

The addition of organic matter amendments, such as compost, fertilizers, and wastes, is a common practice for soil amelioration of contaminated soils [7]. The effect of organic matter amendments on heavy metal bioavailability depends on the nature of the organic matter, their microbial degradability, salt content and effects on soil $\mathrm{pH}$ and redox potential, as well as on the particular soil type and metals concerned [8].

The use of organic fertilizers influences the physicochemical properties of soils and improves the conditions for the development of crops. Organic fertilizers can neutralize or reduce the acidity of the soil and increase the content of certain microelements, such as $\mathrm{Zn}$ and $\mathrm{Cu}$. The efficiency of organic fertilization is manifested in rapid growth, earlier maturation, improvement in the flammability of leaves, their mass and yield [9]. There is evidence that the use of combined inorganic and organic fertilizers can improve the growth and quality of tobacco $[10]$.

The increasing application of organic fertilizers improves the soil's ability to supply nutrients, thus providing sufficient amounts of $\mathrm{N}, \mathrm{P}$, and $\mathrm{K}$ for the development of tobacco [11]. On the other hand, organic fertilizers can improve the resistance of the tobacco plant to diseases [12].

The main objective of this paper is to conduct a systematic study, which will help to determine the impact of organic soil amendments on the uptake of the heavy metals, micro and macroelements by enhanced tobacco $\mathrm{NBCu} 10-8 \mathrm{~F} 3$, as well as the potential of the plant for phytoremediation of heavy metal contaminated soils.

\section{MATERIAL AND METHODS}

The soil used in this experiment was collected from the surface soil horizon $(0-20 \mathrm{~cm})$ from sites situated at a distance of $0.5 \mathrm{~km}$ from the vicinity of the area contaminated by the NonFerrous-Metal Works (MFMW) near Plovdiv, Bulgaria. The pot experimental was a randomized complete block design containing nine treatments and three replications (27 pots): 1 -addition of $5 \%$ of vermicompost to the soil, 2 - addition of $10 \%$ of vermicompost to the soil, 3 - addition of $15 \%$ of vermicompost to the soil, 4 - addition of $30 \%$ of vermicompost to the soil, 5 - addition of 5\% of compost to the soil, 6 - addition of $10 \%$ of compost to the soil, 7 addition of $15 \%$ of compost to the soil, 8 - addition of $30 \%$ of compost to the soil, 9 - control variant.

Soils were passed through a 2-cm sieve. Amendments were added and thoroughly mixed by hand. The pots were filled with $3 \mathrm{~kg}$ soil. Three control pots were also set up without 
amendment. Pots were watered and stored in a greenhouse, where they were left to settle a minimum of 6 weeks at room temperature before planting the enhanced tobacco.

Characteristics of soils and organic amendments are shown in Table 1. The soil used in this experiment was slightly alkalic, with moderate content of organic matter and essential nutrients ( $\mathrm{N}, \mathrm{P}$ and $\mathrm{K}$ ). The psedo-total content of $\mathrm{Zn}, \mathrm{Pb}$ and $\mathrm{Cd}$ is extremely high $(2544.8 \mathrm{mg} / \mathrm{kg} \mathrm{Zn}$, $2429.3 \mathrm{mg} / \mathrm{kg} \mathrm{Pb}$ and $51.5 \mathrm{mg} / \mathrm{kg} \mathrm{Cd}$, respectively) and exceeds the maximum permissible concentrations $(320 \mathrm{mg} / \mathrm{kg} \mathrm{Zn}, 100 \mathrm{mg} / \mathrm{kg} \mathrm{Pb}$ and $2.0 \mathrm{mg} / \mathrm{kg} \mathrm{Cd})$. Soil properties are a prerequisite for low to moderate metal mobility, as confirmed by the results of DTPA-extracted $\mathrm{Pb}, \mathrm{Cd}$ and $\mathrm{Zn}$ (mean for $\mathrm{Pb}$ and $\mathrm{Zn}$, and high for $\mathrm{Cd}$ ).

Table 1: Characterization of the soil and the organic amendments used in the experiment

\begin{tabular}{|l|c|c|c|}
\hline Parameter & Soil & Compost & Vermicompost \\
\hline $\mathrm{pH}$ & 7.6 & 6.9 & 7.5 \\
\hline Organic matter, \% & 3.99 & 72.10 & 38.58 \\
\hline N Kjeldal, \% & 0.24 & 2.22 & 1.57 \\
\hline Pseudo-total P, mg/kg & 731 & 12654 & 10211 \\
\hline Pseudo-total K,nmg/kg & 4675 & 6082 & 10495 \\
\hline Pseudo-total Ca, mg/kg & 10607.5 & 32158.7 & 31848 \\
\hline Pseudo-total Mg, mg/kg & 9577.5 & 2086.5 & 7754.9 \\
\hline Pseudo-total Cu, mg/kg & 124.8 & 43.23 & 53.33 \\
\hline Pseudo-total Fe, $\mathrm{mg} / \mathrm{kg}$ & 41650.9 & 3177.31 & 11813.7 \\
\hline Pseudo-total Mn, mg/kg & 1244.5 & 360.48 & 423.3 \\
\hline Pseudo-total Pb, mg/kg & 2429.3 & 12.0 & 32.3 \\
\hline Pseudo-total Zn, $\mathrm{mg} / \mathrm{kg}$ & 1430.7 & 170.8 & 270.3 \\
\hline Pseudo-total Cd, mg/kg & 31.4 & 0.19 & 0.69 \\
\hline DTPA - extractable Pb, mg/kg & 849.1 & & \\
\hline DTPA - extractable Zn, mg/kg & 236.8 & & \\
\hline DTPA - extractable Cd, mg/kg & 36.8 & & \\
\hline
\end{tabular}

The test plant was enhanced tobacco $\mathrm{NBCu} 10-8 \mathrm{~F} 3$. The enhanced tobacco plants were grown in a climate chamber with regular watering and random rotation of the position of the pots. After 90 days, all plants were harvested.

The content of heavy metals, micro and macroelements was determined in the different parts of enhanced tobacco - roots, stems and leaves. The plant samples were treated by the method of microwave mineralization.

The pseudo-total content of metals in soils was determined in accordance with ISO 11466[13]. The available (mobile) heavy metals contents were extracted in accordance with ISO 14870 by a solution of DTPA [14].

To determine the heavy metal content in the plant and soil samples, inductively coupled emission spectrometer (Jobin Yvon Horiba "ULTIMA 2", France) was used.

\section{RESULTS AND DISCUSSION}

Table 2 presents the results obtained for the content of heavy metals, micro and macroelements in the vegetative organs of enhanced tobacco without amendments. The root system is a major route for the absorption of heavy metals into plants. Once they have entered the roots, they can be stored or moved to the stems. The results obtained show that a significant portion of $\mathrm{Pb}, \mathrm{Zn}$ 
and $\mathrm{Cd}$ is accumulated at the roots of the enhanced tobacco $\mathrm{NBCu} 10-8 \mathrm{~F} 3$. These results are confirming the results obtained by [15], who found that $\mathrm{Pb}$ accumulated mainly in the roots of tobacco.

The content of $\mathrm{Cd}$ is higher in the tobacco leaves than in the root system and stems, which is in line with the results of other authors [16-17]. The greater accumulation of $\mathrm{Cd}$ in tobacco leaves is probably due to $\mathrm{Cd}$ absorption from the soil through the root system of the plant and their movement through the conductive system. It has been found that cadmium can be accumulated in tobacco leaves in an amount 10 times higher than that in the soil [18]. This is consistent with what was found by [19], who found that tobacco had an extraordinary ability to digest $\mathrm{Cd}$ as compared to other plants when grown on Cd contaminated soils.

Table 2: Content of heavy metals, micro and macroelements $(\mathrm{mg} / \mathrm{kg})$ in enhanced tobacco $\mathrm{NBCu} 10-8 \mathrm{~F} 3$ (without amendments)

\begin{tabular}{|c|c|c|c|c|c|c|c|c|c|c|}
\hline & $\mathrm{Pb}$ & $\mathrm{Zn}$ & $\mathrm{Cd}$ & $\mathrm{Cu}$ & $\mathrm{Fe}$ & $\mathrm{Mn}$ & $\mathrm{K}$ & $\mathrm{Ca}$ & $\mathrm{Mg}$ & $\mathrm{P}$ \\
\hline Roots & 152.0 & 405.9 & 50.5 & 72.2 & 629.7 & 28.4 & 12365 & 12341 & 2598.3 & 1132,3 \\
\hline Stems & 24.4 & 86.9 & 20.1 & 6.0 & 12.6 & 1.6 & 10003 & 3994 & 366.1 & 419.6 \\
\hline Leaves & 75.5 & 119.6 & 125.4 & 20.4 & 211.7 & 53.0 & 18569 & 14541 & 2280.0 & 778.8 \\
\hline
\end{tabular}

The results for the influence of organic meliorants on the accumulation and distribution of heavy metals, micro and macroelements in the enhanced tobacco $\mathrm{NBCu} 10-8 \mathrm{~F} 3$ are shown in Figure 1. The addition of compost and vermicompost results in a decrease in $\mathrm{Pb}, \mathrm{Zn}$ and $\mathrm{Cd}$ content in the roots, stems and leaves of tobacco, as this decrease is more pronounced when $30 \%$ of compost and 30\% vermicompost is imported. The results obtained may be explained by the amount of heavy metal mobile forms. The addition of compost and vermicompost to the soil leads to the decrease of mobile forms, resulting in lower accumulation of these elements in the leaves of the plants.

The distribution of heavy metals, micro and macroelements in the organs of enhanced tobacco has selective character specific for individual elements. The main part of heavy metals (except $\mathrm{Cd})$, microelements and macroelements $(\mathrm{P}$ and $\mathrm{Mg})$ are accumulated in roots. The distribution of heavy metals, micro and macroelements in the organs of the enhanced tobacco with the addition of compost and vermicompost follows the same relation observed in the control sample (Fig. 1).

The $\mathrm{Pb}$ content in tobacco leaves reached to $75.5 \mathrm{mg} / \mathrm{kg}$ in the control, and from 13.1 to $67.1 \mathrm{mg} / \mathrm{kg}$ in variants with incorporation of compost and from 17.4 to $42.0 \mathrm{mg} / \mathrm{kg}$ in variants with incorporation of vermicompost. According to Tso [20], the content of $\mathrm{Pb}$ in tobacco leaves varies widely - from 0 to $200 \mathrm{mg} / \mathrm{kg}$, and depends largely on the soil characteristics, the type and variety of tobacco, as well as the place of cultivation [21]. The incorporation of compost and vermicompost leads to a decrease of the $\mathrm{Pb}$ content in tobacco leaves (Fig.1).

The Cd content in tobacco leaves reached to $125.4 \mathrm{mg} / \mathrm{kg}$ in the control, and from 40.7 to 94.1 $\mathrm{mg} / \mathrm{kg}$ in variants with incorporation of compost and from 54.4 to $99.6 \mathrm{mg} / \mathrm{kg}$ in variants with incorporation of vermicompost. According to Golia et al. [22] the content of $\mathrm{Cd}$ in tobacco ranges from 0.5 to $3.5 \mathrm{mg} / \mathrm{kg}$, while Tso [20] reports values reaching up to $11.6 \mathrm{mg} / \mathrm{kg}$. According to Mench et al. [23] and Sappin-Didier et al. [24], Cd content in tobacco leaves varies from 40 to $120 \mathrm{mg} / \mathrm{kg}$ depending on the soil characteristics. The results obtained are consistent with the values reported in other literature sources [25-26] and higher than the concentrations considered 
critical in plants $(5-30 \mathrm{mg} / \mathrm{kg})$ [27]. Incorporation of compost and vermicompost leads to a reduction of $\mathrm{Cd}$ in tobacco leaves.

The $\mathrm{Zn}$ content in tobacco leaves reached to $183.6 \mathrm{mg} / \mathrm{kg}$ in the control, and from 105.0 to 197.8 $\mathrm{mg} / \mathrm{kg}$ in variants with incorporation of compost and from 77.4 to $138.9 \mathrm{mg} / \mathrm{kg}$ in variants with incorporation of vermicompost. According to Jones et al.[28] and Campbell [29] the optimum amount of $\mathrm{Zn}$ in the tobacco is in the range from 20 to $60(80) \mathrm{mg} / \mathrm{kg}$, and excess were observed in values above 80 to $100 \mathrm{mg} / \mathrm{kg}$.

According to Campbell [29] the optimum values of $\mathrm{Cu}$ for tobacco are $5-10 \mathrm{mg} / \mathrm{kg}$, whereas Yancheva [30] found that level of $\mathrm{Cu}$ in tobacco is in the range $11.9-13.3 \mathrm{mg} / \mathrm{kg}$. The values identified by us for $\mathrm{Cu}$ in the leaves from untreated tobacco plants reached to $20.4 \mathrm{mg} / \mathrm{kg}$. The incorporation of compost decreases the content of $\mathrm{Zn}$ and $\mathrm{Cu}$ in tobacco leaves (Fig. 1).

The Fe content in tobacco leaves reached to $211.7 \mathrm{mg} / \mathrm{kg}$ in the control, and from 70.2 to 221.1 $\mathrm{mg} / \mathrm{kg}$ in variants with incorporation of compost and from 69.9 to $108.4 \mathrm{mg} / \mathrm{kg}$ in variants with incorporation of vermicompost. In scientific literature the optimal Fe content in tobacco leaves is 50 to $300 \mathrm{mg} / \mathrm{kg}$ [28], whereas $40-50 \mathrm{mg} / \mathrm{kg}$ is considered low concentration depending on the stage of plant development [30].

Figure 1: Effect of organic amendments on distribution of heavy metals in vegetative organs of enhanced tobacco $\mathrm{NBCu} 10-8 \mathrm{~F} 3$

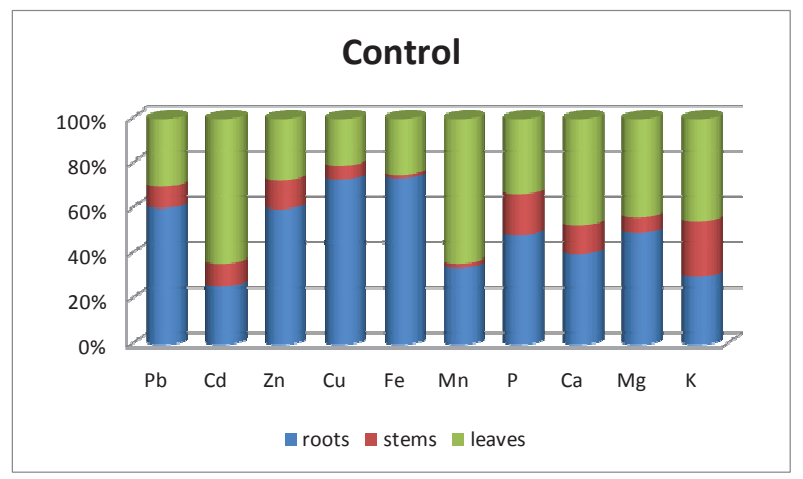




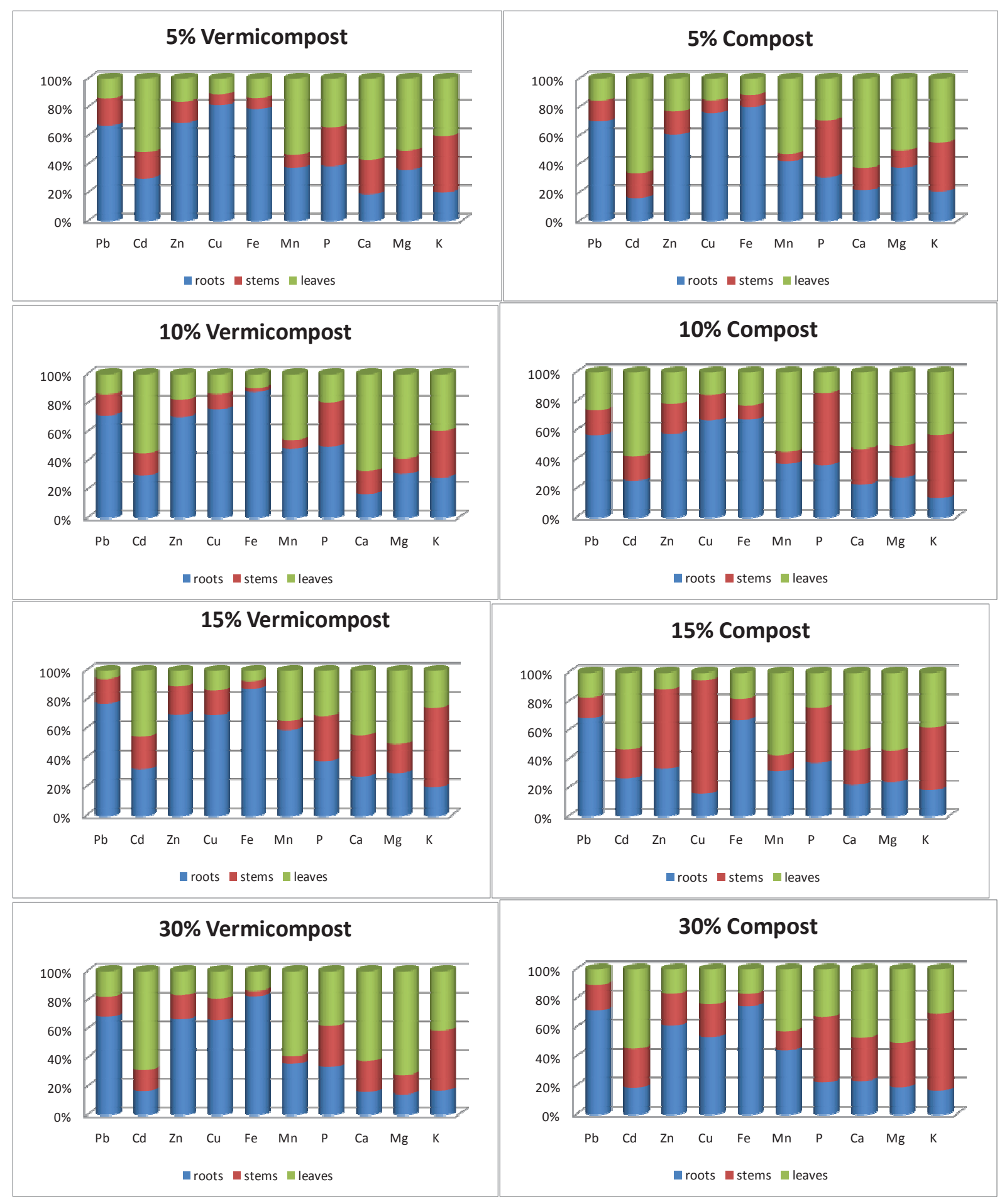

The incorporation of compost leads to decrease of the Fe content in the tobacco leaves.

The Mn content in tobacco leaves reached to $53.0 \mathrm{mg} / \mathrm{kg}$ in the control, and from 37.6 to $66.5 \mathrm{mg} / \mathrm{kg}$ in variants with incorporation of compost and from 29.6 to $46.5 \mathrm{mg} / \mathrm{kg}$ in variants with incorporation of vermicompost. The incorporation of $15 \%$ and $30 \%$ compost results in increased Mn content in leaves (Figure 1).

The content of $\mathrm{P}$ in the leaves of tobacco plants reached to $778.8 \mathrm{mg} / \mathrm{kg}$ in the control, and from 793.1 to $1953.7 \mathrm{mg} / \mathrm{kg}$ in variants with incorporation of compost and from 652.6 to $1689.6 \mathrm{mg} / \mathrm{kg}$ 
in variants with incorporation of vermicompost. Phosphorus content in tobacco leaves, depending on the stage of development, ranges from 0.1 to $1 \%$ [28]. The incorporation of compost and vermicompost results in increased $\mathrm{P}$ content in leaves.

The content of $\mathrm{K}$ in the leaves of tobacco plants reached to $1.85 \%$ in the control, and from 2.5 to $6.2 \% \mathrm{mg} / \mathrm{kg}$ in variants with incorporation of compost and from 2.4 to $3.6 \mathrm{mg} / \mathrm{kg}$ in variants with incorporation of vermicompost. The incorporation of compost and vermicompost results in increased $\mathrm{K}$ content in leaves.

The $\mathrm{Ca}$ content in tobacco leaves reached to $1.5 \%$ in the control, and from 0.9 to $1.8 \%$ in variants with incorporation of compost and from 1.3 to $2.0 \%$ in variants with incorporation of vermicompost. The incorporation of $30 \%$ compost in soil results in a decrease of the Ca content in tobacco leaves (up to $0.9 \%$ in the leaves).

The minimum $\mathrm{Mg}$ content in tobacco leaves, where symptoms of insufficiency do not appear, is about $0.25 \%$ [20]. According to McCants and Woltz [31] the content of Mg in technically senescence leaves of oriental tobacco is changed in a narrow range - from 0.33 to $0.69 \%$ and depends mainly on the location of the leaves to the stem. The organic additives lead to increase in the Mg content in tobacco leaves (Fig. 1).

The Translocation Factor (TF=[Metal] shoots/[Metal] roots) provides information on the ability of plants to digest heavy metals through the roots and to move them to the above-ground mass (leaves). The results we obtained show that, with respect to $\mathrm{Pb}$, the translocation factor for plants without the importation of additives reaches up to 0.50 , for $\mathrm{Cd}$ up to 2.48 and for $\mathrm{Zn}$ up to 0.45 . Higher values for $\mathrm{Cd}$ are probably a consequence of the greater ability of this element to accumulate in the above-ground mass than in the roots, which is consistent with the results of Wagner and Yergan [16] and Fässler et al. [17]. The results of the study show that enhanced tobacco accumulates significant amount of $\mathrm{Cd}$ in the leaves and has a relatively higher potential for phytoextraction. The high concentration of $\mathrm{Cd}$ in the leaves and the high translocation factor indicate the possibility of enhanced tobacco to be used in phytoextraction. However, the addition of compost and vermicompost reduces the ability to digest the heavy metals in the leaves, and phytoremediation potential of enhanced tobacco $\mathrm{NBCu} 10-8 \mathrm{~F} 3$.

\section{CONCLUSIONS}

Based on the results obtained regarding the impact of organic soil amendments on the uptake of the heavy metals by enhanced tobacco, as well as the potential of the plant for phytoremediation of heavy metal contaminated soils, the following conclusions can be made:

1. The distribution of the heavy metals, micro and macroelements in the organs of the enhanced tobacco $\mathrm{NBCu} 10-8 \mathrm{~F} 3$ has a selective character and depended above all on the parts of the plants and the element that was examined. $\mathrm{Pb}, \mathrm{Zn}, \mathrm{Cu}, \mathrm{Fe}, \mathrm{Mn}, \mathrm{P}$ and $\mathrm{Mg}$ distribution in tobacco decreases in the following order: roots $>$ leaves $>$ stems, and for $\mathrm{Cd}, \mathrm{K}$, and $\mathrm{Ca}$ - leaves $>$ roots $>$ stems.

2. The incorporation of compost and vermicompost leads to decrease in the content of heavy metals in the tobacco leaves and increase uptake of $\mathrm{K}, \mathrm{Ca}$ and $\mathrm{Mg}$.

3. The high concentration of $\mathrm{Cd}$ in the leaves and the high translocation factor indicate the possibility of enhanced tobacco to be used in phytoextraction. However, the addition of compost and vermicompost further reduces the ability to digest the heavy metals in the leaves, and phytoremediation potential of enhanced tobacco NBCu 10-8F3. 
Acknowledgement: The financial support by the Bulgarian National Science Fund Project DFNI H04/9 is greatly appreciated.

\section{REFERENCES}

[1] Salt D. E., Smith R.D., Raskin I. (1998) Phytormediation. Annual Rev. Plant Physiol. Plant Mol. Biol., vol.49, pp.643-668.

[2] Mench, M., Martin, E. (1991) Mobilization of cadmium and other metals from two soils by root exudates of Zea mays L., Nicotiana tabacum L., and Nicotiana rustica L., Plant and soil, vol.132, no.2,pp. 187-196.

[3] Mench, M.J., Didier, V.L., Loeffler, M., Gomez, A., Masson, P. (1994) A mimicked in-situ remediation study of metal contaminated soils with emphasis on cadmium and lead, J. Environ. Qual., vol. 23, pp.58-63.

[4] Guadagnini, M.. (2000) In vitro-Breeding for Metal-Accumulation in Two Tobacco (Nicotiana tabacum) Cultivars, Innagural-Dissertation No. 1288 derMathematisch Naturwissenschftlichen Fakult"at der Universit”at Freiburg in der Schweiz. pp. 109.

[5] Herzig, R., Guadagnini, M., Rehnert, A., Erismann, K.H. (2003) Phytoextraction efficiency of in vitro bred tobacco variants using a non-GMO approach. In: Vanek T, Schwitzgu'ebel JP, editors. Phytoremediation Inventory - COST Action 837 View. Prague (Czech Republic): UOCHB AVCR. p. 73.

[6] PHYTAC (2005) Development of systems to improve phytoremediation of metal contaminated soils through improved phtoaccumulation (QLRT-2001-00429 \& 200102778 NAS). Final report 5th Framework Programme, Dec. 2005, p. 160-190.

[7] Clemente, R., Walker, D.J., Bernal, M.P. (2005) Uptake of heavy metals and As by Brassica Juncea grown in a contamination soil in Arnalcollar (Spain): The effect of soil amendments, Environmental Pollution, vol.136, pp.46 - 58.

[8] Walker, D. J., Clemente, R., Roig, A., Bernal, V. (2003) The effect of soil amendments on heavy metal bioavailability in two contaminated Mediterranean soils, Environ Pollution, vol.22, pp. $303-312$.

[9] Hu, Z. (2004) Effect of bio-organic compound vermicompost on improvement of tobacco quality, Chinese Agricultural Science Bulletin, vol.20, no.3, pp. 157-158.

[10] Wang, S.S., Shi, Q.M., Li, W.Q., Niu, J.F., Li, C.J., Zhang, F.S. (2008), Nicotine concentration in leaves of fluecured tobacco plants as affected by removal of the shoot apex and lateral buds, J. Integr. Plant Biol., vol.50, pp. 958-964.

[11] Cao, P.Y., Lu, S.J., Zhang, W.S. (2004) Advances in soil organic matter contents and vermicomposts application in tobacco growing areas, Acta Tabacaria Sinica, vol.10, no.6, pp 40-42.

[12] Li, C.X. (2007) Effect of EM bio-organic vermicompost on tea garden, J. Tea Business, vol.29, no.2, pp. 65-66.

[13] ISO 11466 (1995) Soil quality. Extraction of trace elements soluble in aqua regia.

[14] ISO 14870 (2001) Soil Quality-Extraction of Trace Elements by Buffered DTPA Solution.

[15] del Piano, L., Abet, M., Sorrentino, Barbato, L., Sicignano, M., Cozzolino, E., Cuciniello, A. (2008) Uptake and distribution of lead in tobacco (Nicotiana tabacum L.), Journal of Applied Botany and Food Quality, vol.82, pp.21 - 25, 2008.

[16] Wagner, G.J.,Yergan, R (1986) Variation in Cd accumulation potential and tissue distribution of Cd in tobacco, Plant. Physiol., vol. 82, pp. 274-279.

[17] Fässler, E., Robinson, B.H., Gupta, S.K,, Schulin, R. (2010) Uptake and allocation of plant nutrients and Cd in maize, sunflower and tobacco growing on contaminated soil and the effect of soil conditioners under field conditions, Nutrient Cycling in Agroecosystems, vol.87(3), pp. 339-352. 
[18] Anonymous (1995) Encyclopedia of Analytical Science, Academic Press: London, San Diego New York, Boston, Tokyo, Toronto, vol.1, pp.418-419.

[19] Yeargan, R., Maiti, I.B., Nielsen, M.T., Hunt, A.G., Wagner, G.J. (1992) Tissue partitioning of cadmium in transgenic tobacco seedlings and field grown plants expressing the mouse metallothionein I gene, Transgenic Res., vol.1, pp.261-267.

[20] Tso, T. C. (1991) Production, physiology and biochemistry of tobacco plant. Beltsville, MD, Ideals.

[21] Lugon-Moulin, N., Zhang, M., Gadani, F., Rossi, L., Koller, D., Krauss, M., Wagner, G. I. (2004) Critical review of the science and options for reducing cadmium in tobacco (Nicotiana tabacum L.) and other plants, Adv. Agron.,vol. 83, pp.111-180.

[22] Golia, E.E., Dimirkou, A., Mitsios, I. K. (2007) Accumulation of metals on tobacco leaves (primings) grown in an agricultural area in relation to soil, Bull Environ Contam Toxicol., vol.79 (2), pp. 158-162.

[23] Mench, M.J., Didier, V.L., Loeffler, M., Gomez, A., Masson, P. (1994) A mimicked in-situ remediation study of metal contaminated soils with emphasis on cadmium and lead, J. Environ. Qual., vol. 23, pp.58-63.

[24] Sappin-Didier, V., Mench, M., Gomez, A., \& Masson, P. (1997) Evaluation by single extractants of $\mathrm{Cd}$ immobilization following the addition of inorganic amendments in two metal contaminated soils, Comptesrendus de 1.academie des sciences. Serie III. Sciences de la Vie, vol. 320, pp. 413-419.

[25] Adamu, C.A., Mulchi, C.L., Bell, P.F. (1989) Relationships between soil pH, clay, organic matter and CEC [cation exchange capacity] and heavy metal concentrations in soils and tobacco, Tob. Sci., vol. 33, pp. 96-100.

[26] Bell, P.F., Mulchi, C.Z., Chaney, R.Z. (1992) Microelement concentration in Maryland air-cured tobacco, Commun. Soil Sci. Plant Anal., vol.23, no.13-14, pp. 1617-1628.

[27] Kabata-Pendias, A., Pendias, H. (2001) Trace elements in soils and plants, 3rd ed. CRC, New York.

[28] Jones, J., Wolf, B., Mills, H.A. Plant Analysis Handbook. Micro-Macro Publishing Inc., 1991.

[29] Campbell, C. Reference Sufficiency Ranges Field Crops, Tobacco, Flue-cured, 2000. www.ncagr.com/agronomi/saaesd/fluecure.htm

[30] Wagner, G.I. (1994) Accumulation of cadmium in crop plants and its consequences to human health, Adv. Agronomy, vol.51, pp.173-212.

[31] Yancheva, D. (2002) Mineral composition of the oriental tobacco leaves depending on the nitrogen vermicompost rate", In Proc. The Second Balkan Scientific Conference Quality and efficiency of the tobacco production, treatment and processing, Plovdiv, pp.162-166. 